\section{Specific language impairment in an adult with type I bipolar disorder - a case report}

\author{
Distúrbio específico de linguagem em \\ adulto com transtorno bipolar do tipo I - \\ relato de caso
}

\author{
Dear Editor, \\ Specific language impairment (SLI) is defined as a disorder
} of oral language abilities which are clearly below expected after controlling for age and developmental level. It affects multiple areas such as semantics, syntax, discourse and literacy acquisition. ${ }^{1}$ SLI is a common disorder, with a prevalence of 3 to $10 \%$ of children; ${ }^{2}$ however, this diagnosis is often overlooked in our setting.

Bipolar disorder (BD) is a common mood disorder characterized by episodes that might include mania, depression and euthymia. Some cognitive deficits have been described in BD individuals, with some studies suggesting that verbal functions deficits would be the most prominent ones. ${ }^{3}$ It has been suggested that verbal memory deficits could be endophenotypes of $\mathrm{BD}$, highlighting the importance of evaluating verbal abilities in individuals with such diagnosis.

We would like to describe the neuropsychological evaluation of a patient with type I BD who had previous undiagnosed comorbid SLI and past several academic difficulties.

Case: Patient $\underline{A}$, a 27 y. o. woman, has recently started a marketing degree. She was referred to investigate inattention and low academic performance. During high school, $\underline{A}$ realized she could not do homeworks with friends because she could not follow their reading speed. Also, $\underline{A}$ could not grasp the content of classes as expected by teachers.

Since 2002, she has been treated for type I BD; and had a suicide attempt in 2001. A reported several inattention symptoms, such as daydreaming while talking to others. Her father reported she used to complaint about difficulties to understand movies in her native language; also she could not follow subtitles of movies in foreign languages.

A certified board psychiatrist (PM) conducted the first interview; based on the report of significant difficulties in everyday situations and academic settings, the preliminary diagnostic hypothesis was of mental retardation. ADHD diagnosis seemed unwarranted despite the self and parent reports of symptoms of inattention.

Neuropsychological evaluation: A was submitted to a test battery assessing several cognitive functions, including attention, intelligence and language. WAIS-III results revealed a normal global $I Q(I Q=107)$; with significant differences between verbal (100) and non-verbal (116) abilities. Performance on control inhibition and sustained attention test (CPT-II) was normal. A presented significant inattention only during language assessment by a speech therapist (TS). Single word reading was normal, but interpretation, writing and oral comprehension were below expected considering age and $I Q$.

She met criteria for type I BD in Mini-Plus; ${ }^{4}$ A reported significant inattention symptomatology on K-SADS-E, ${ }^{5}$ but these symptoms seemed to be secondary to language impairment; moreover, significant inattention first appeared in early adulthood, suggesting ADHD diagnosis was not likely.

Academic impairment began before BD symptomatology onset. ADHD symptoms were not present in childhood, although academic impairment was already present probably due to SLI. $\underline{A}$ was referred to a speech language therapist; it must be emphasized that the diagnosis of SLI and the documentation of a normal IQ had a positive impact in her self-esteem and autonomy to everyday activities, even before starting specific treatment.

Our case highlights the importance of an extensive cognitive assessment including language performance in psychiatric patients who report significant cognitive complaints and/or academic impairment. The early identification and treatment of learning and/ or language disorders potentially lead to a better prognosis.

Paulo Mattos, Beatriz Rabelo Centro de Neuropsicologia Aplicada (CNA), Rio de Janeiro (RJ), Brazil Universidade Federal do Rio de Janeiro (UFRJ), Rio de Janeiro (RJ), Brazil

Fernanda Gueiros Private practice

Tania Soares, Gabriel Coutinho Centro de Neuropsicologia Aplicada (CNA), Rio de Janeiro (RJ), Brazil Study accomplished at the Centro de Neuropsicologia Aplicada (CNA), Rio de Janeiro (RJ), Brazil

Disclosures

\begin{tabular}{|c|c|c|c|c|c|c|c|}
\hline $\begin{array}{l}\text { Writting group } \\
\text { member }\end{array}$ & Employment & $\begin{array}{l}\text { Research } \\
\text { grant }^{1}\end{array}$ & $\begin{array}{c}\text { Other research grant } \\
\text { or medical } \\
\text { continuous } \\
\text { education }^{2}\end{array}$ & $\begin{array}{l}\text { Speaker's } \\
\text { honoraria }\end{array}$ & $\begin{array}{l}\text { Ownership } \\
\text { interest }\end{array}$ & $\begin{array}{l}\text { Consultant/ } \\
\text { Advisory } \\
\text { board }\end{array}$ & Other $^{3}$ \\
\hline Paulo Mattos & UFRJ & $\begin{array}{c}\text { Janssen- } \\
\text { Cilag* }^{*}\end{array}$ & Janssen-Cilag* & $\begin{array}{l}\text { Janssen- } \\
\text { Cilag* }^{*}\end{array}$ & - & Janssen-Cilag* & - \\
\hline Beatriz Rabelo & $\begin{array}{l}\text { Consultório } \\
\text { particular }\end{array}$ & - & - & - & - & - & - \\
\hline Fernanda Gueiros & CNA & - & - & - & - & - & - \\
\hline Tania Soares & CNA & - & - & - & - & - & - \\
\hline Gabriel Coutinho & CNA & - & - & - & - & - & - \\
\hline $\begin{array}{l}\text { Modest } \\
\text { * Significant } \\
\text { Note: UFnificant. Amou }\end{array}$ & Federal do Ri & רeiro; $C N A=$ & tro de Neuropsicologia & da. & icipation, nc & ly to the auth & \\
\hline
\end{tabular}




\section{References}

1. Bishop DV, Snowling MJ. Developmental dyslexia and specific language impairment: same or different? Psychol Bull. 2004;130(6):858-86.

2. Tomblin JB, Records NL, Buckwalter P, Zhang X, Smith E, O'Brien M Prevalence of specific language impairment in kindergarten children. J Speech Lang Hear Res. 1997;40(6):1245-60.

3. Bora E, Yucel M, Pantelis C. Cognitive endophenotypes of bipolar disorder: a meta-analysis of neuropsychological déficits in euthymic patients and their first-degree relatives. J Affect Disord. 2009;113(12): 1-20.

4. Amorim P. Mini International Neuropsychiatric Interview (MINI): validation of a short structured diagnostic psychiatric interview. Rev Bras Psiquiatr. 2000;22(3):106-15.

5. Grevet $\mathrm{EH}$, Bau $\mathrm{CH}$, Salgado $\mathrm{CA}$, Fischer A, Victor MM, Garcia C, de Sousa NO, Nerung L, Belmonte-De-Abreu P. Interrater reliability for diagnosis in adults of attention-deficit hyperactivity disorder and oppositional defiant disorder using K-SADS-E. Arq Neuropsiquiatr. 2005;3(2A):307-10. 